\title{
Iatrogenic keratoconjunctivitis sicca in a dog
}

\author{
Ceratoconjuntivite seca iatrogênica em cão
}

\author{
Denise Eliza de Almeida ${ }^{1}$ Fabricio Villela Mamede $^{2}$ \\ Juan Pablo Duque Ortiz ${ }^{3}$ José Luiz Laus ${ }^{4}$
}

- RELATO DE CASO -

\begin{abstract}
Qualitative and quantitative abnormalities in primary components of the tear can alter the dynamics of the lacrimal film, compromising its function. Lipids, an aqueous fraction and mucoproteins constitute the lacrimal film. Keratoconjunctivitis sicca (KCS) is a disease commonly diagnosed in dogs. It is characterized by the deficiency of the aqueous fraction in the lacrimal film that results in dryness, inflammation of the conjunctive and cornea with progressive corneal illness and reduction of vision and pain. Due to the significant contribution of the third eyelid lacrimal gland to the production of the aqueous fraction of the lacrimal film, the removal of this gland when prolapsed is an important cause of iatrogenic keratoconjuctivitis sicca. This paper describes a clinical case of iatrogenic keratoconjuctivitis sicca in a 10 monthold Boston Terrier which was caused by the removal of the third eyelid lacrimal gland due to its prolapse.
\end{abstract}

Key words: iatrogenic keratoconjunctivitis sicca, dry eye, cherry eye. RESUMO

Anormalidades quali-quantitativas em componentes primários da lágrima podem alterar a dinâmica do filme lacrimal, comprometendo sua função. O filme lacrimal é composto por lipídios, uma fração aquosa e por mucoproteínas. A ceratoconjuntivite seca (CCS) é uma enfermidade freqüentemente diagnosticada em cães, caracterizada pela deficiência da fração aquosa do filme lacrimal, resultando em dessecação e inflamação da conjuntiva e córnea, dor, doença corneana progressiva e redução da visão. Devido à contribuição significativa da glândula da terceira pálpebra na produção da porção aquosa do filme lacrimal, a remoção desta glândula, quando prolapsada, constitui-se em importante causa de CCS iatrogênica. Este trabalho relata um caso clínico de ceratoconjuntivite seca iatrogênica, em um cão da raça Boston Terrier de 10 meses de idade, causada pela remoção cirúrgica da glândula lacrimal da terceira pálpebra, quando esta encontrava-se prolapsada.

Palavras-chave: ceratoconjuntivite seca iatrogênica, olho seco, prolapso da glândula lacrimal.

\section{INTRODUCTION}

Keratoconjunctivitis sicca $(\mathrm{KCS})$ is a chronic inflammatory disease frequently diagnosed in dogs and is caused by the deficiency of the aqueous component of the lacrimal film (MOORE, 1998; MORGAN et al., 1991; WILKIE, 1993). GELLAT et al. (1975), GELLAT (1991) and SAITO et al. (2001) reported that the production of the aqueous fraction of the tear is done by the main lacrimal gland $(70 \%)$ and the third eyelid lacrimal gland (30\%). Abnormalities within the quality and quantity of the aqueous component can alter the dynamics of the lacrimal film and compromise its function

\footnotetext{
'Médico Veterinário Pós-graduando do Programa de Pós-graduação em Cirurgia Veterinária, área de concentração em Cirurgia Veterinária, Curso de Doutorado, Faculdade de Ciências Agrárias e Veterinárias (FCAV), Universidade Estadual Paulista (UNESP, Campus de Jaboticabal.

${ }^{2}$ Médico Veterinário Pós-graduando do Programa de Pós-graduação em Medicina Veterinária, área de concentração em Cirurgia Veterinária, Curso de Mestrado, Faculdade de Medicina Veterinária e Zootecnia, Universidade Estadual Paulista, Câmpus de Botucatu.

${ }^{3}$ Médico Veterinário, Pós-graduando do Programa de Pós-graduação em Cirurgia Veterinária, área de concentração em Cirurgia Veterinária, Curso de Mestrado, FCAV, UNESP, Campus de Jaboticabal.

${ }^{4}$ Médico Veterinário, Professor Titular, Departamento de Clínica e Cirurgia Veterinária, FCAV, UNESP, Campus de Jaboticabal. Autor para correspondência: Prof. Dr. José Luiz Laus, Professor Titular do Departamento de Clínica e Cirurgia, FCV, UNESP, Campus de Jaboticabal. End.: Via de Acesso Prof. Paulo Donato Castellane, KM 5, Rural, 14884-900, Jaboticabal, SP, E-mail:jllaus@fcav.unesp.br
} 
(McLAUGHLIN et al, 1988; MOORE, 1998) due to the complex interaction between the primary components of the tear (lipid, aqueous fraction and mucoprotein).

The aqueous component of the tear is responsible for the maintenance of the corneal integrity. Moreover, the aqueous component decreases the friction attributed to the movement of eyelids, removes debris, moistens the cornea, and serves as a source of oxygen and glucose to the cornea. The deficiency of the aqueous fraction of the tear increases the lacrimal film osmolarity, promotes conjunctivitis, keratitis and progressive corneal disease. In some cases, secondary corneal ulcers may be observed. The chronic deficiency of the lacrimal film usually causes pigmentation and vascularization of the cornea, along with pain and decrease in vision (SANSOM et al., 1995; MOORE, 1998; WILKIE, 1993).

The pathogenesis of KCS may be related to a single process or a combination of conditions that affect the lacrimal glands. Some of the major causes of KCS are: chronic blepharoconjuctivitis, congenital hypoplasia of the main lacrimal gland, use of sulfonamides and topical atropine, loss of parasympathetic innervations of the lacrimal gland, metabolic diseases, immune mediate diseases, distemper and iatrogenic disease (GELLAT, 1991; MOORE, 1998). One of the most common etiology and pathogenesis of the iatrogenic KCS is the excision of the prolapsed third eyelid lacrimal gland (DUGAN et al., 1992; HELPER et al., 1974; KASWAN et al., 1985; MOORE, 1998; MORGAN et al., 1991). The diagnosis of KCS is based on clinical signs and Schirmer's Tear Test (STT1) values less than $10 \mathrm{~mm} /$ min (SANSOM et al., 1995; MOORE, 1998).

A variety of breeds are predisposed to the dorsal prolapse of the third eyelid lacrimal gland, known as cherry eye. Some authors describe that, in dogs with this disease, the connective tissue located between the base of the gland and the periorbital tissue may be poorly developed (STANLEY \& KASWAN, 1994; KASWAN \& MARTIN, 1985). The prolapse is frequently observed in dogs like American and English Cocker Spaniel, English Bulldog, Beagle, Pekingese, Boston Terrier, Basset Hound, Lhasa Apso and Shih Tzu (KASWAN \& MARTIN, 1985; DUGAN et al., 1992; MORGAN et al., 1993). The surgical treatment consists of excising or replacing the prolapsed gland (DUGAN et al., 1992; STANLEY \& KASWAN, 1994). However, its removal may promote or increase the development of KCS because of the important contribution of the third eyelid lacrimal gland on producing the aqueous fraction of the lacrimal film.
The iatrogenic condition happens especially when the lacrimal function is already compromised or when the procedure is performed in breeds predisposed to the disease (KASWAN \& MARTIN, 1985; McLAUGHLIN et al., 1988; DUGAN et al., 1992; MORGAN et al., 1993; STANLEY \& KASWAN, 1994). HELPER et al. (1974) and GELLAT et al. (1975) described that the excision of the third eyelid gland promoted a decrease in the STT1 lacrimal volume of 29 to $57 \%$, but no clinical signs of KCS were evident. BROOKS (1991) described in his study that the excision of the prolapsed gland is potentially able to induce KCS.

\section{CASE REPORT}

A 10-month-old male Boston Terrier (Figure 1A) was presented to the ophthalmologic service of the Hospital Veterinário "Governador Laudo Natel" at the Faculdade de Ciências Agrárias e Veterinárias, Universidade Estadual Paulista, São Paulo, Brazil, with a history of discomfort in the right eye for one month. During anamnesis it was reported that the dog's third eyelid lacrimal gland had been removed due to a prolapse three months earlier.

At the exam, the dog presented good clinical condition. Ophthalmologic exam revealed the right eye with mucous discharge over the eyelid and ocular surface. Moreover, hyperemic conjunctiva, blepharospasm and photophobia were also observed. Schirmer's tear test 1 (STT1) was performed and revealed values of $0 \mathrm{~mm} / \mathrm{min}$. and $28 \mathrm{~mm} / \mathrm{min}$. for the

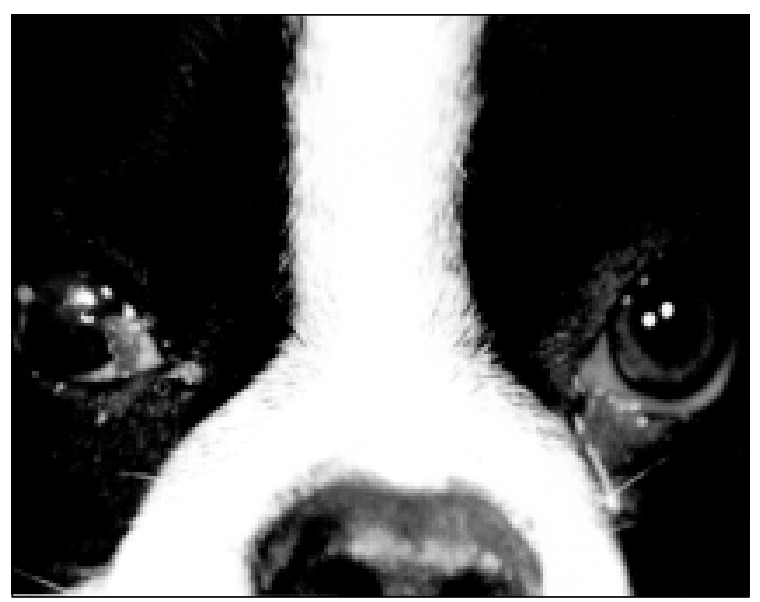

Figure 1A - Photographic image of a male, 10 months old, Boston Terrier. Note the loss of brightness of the cornea and accumulation of mucous discharge, characteristics of dry eye. 
right and left eye respectively. After removing the discharge and cleaning the corneal epithelium of the right eye, slit lamp biomicroscopy revealed moderate congestion of the episcleral capillaries, corneal neovascularization, and edema. Based on these findings, an ophthalmologic scenario of chronic keratitis was found (Figure 1B). The use of fluorescein stain showed that the corneal epithelium was preserved.

Based on STT1 and clinical signs the diagnosis of KCS was made. Moreover, iatrogenic KCS was diagnosed due to the history of third eyelid lacrimal gland removal.

The treatment of the choice was $1 \%$ ciclosporine $^{1}$, twice a day, along with polyacrylic acid ${ }^{2}$ eye drops every 8 hours. Subsequently, response to the treatment was mild with the right value of STT1, which was not adequate.

\section{DISCUSSION}

Authors have reported qualitative (SAITO et al., 2001) and quantitative changes (DUGAN et al., 1992; KASWAN \& MARTIN, 1985; STANLEY \& KASWAN, 1994; MORGAN et al., 1993) in the lacrimal film due to the excision of the prolapsed third eyelid lacrimal gland. HELPER et al. (1974), GELLAT et al. (1975) and McLAUGHLIN et al. (1988) described the occurrence of iatrogenic keratoconjuctivitis sicca induced by the excision of this gland in dogs and cats. MORGAN et al. (1993) concluded that the replacement of the gland is the treatment of choice in breeds predisposed to KCS in which the prolapse of third eyelid gland is common. In this case report, the diagnosis of iatrogenic

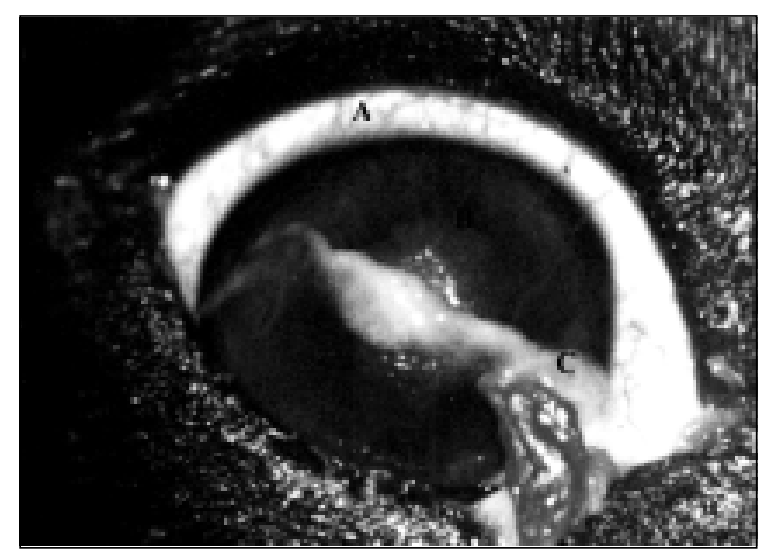

Figure 1B - Note (A) conjunctival hyperemia, (B) corneal vascularization and $(\mathrm{C})$ thick mucous discharge. keratoconjunctivitis sicca in the right eye was based on the Schirmer's Tear Test 1 (STT1) values $(0 \mathrm{~mm} /$ min.-OD) and the clinical signs. The iatrogenic KCS occurred due to the excision of the lacrimal gland. The short period of time between the excision of the gland and the occurrence of the first clinical signs of ocular discomfort ( 2 months) in this young Boston Terriers caught the researcher's attention for the iatrogenic condition.

The possibility of KCS occurrence after excision of the third eyelid lacrimal gland in young dog breeds, that have not been considered predisposed to this disease leads us to cite HELPER et al. (1974). He described the reduction of STT1 values of $29 \%$ to $57 \%$ in dogs subjected to the removal of this gland. In addition, this case report leads us to mention the study performed by MORGAN et al. (1993). He described that the removal of the third eyelid lacrimal gland can contribute to the development of KCS even if the main lacrimal gland is present and producing $43 \%$ to $65 \%$ of the aqueous fraction of the lacrimal film.

\section{CONCLUSIONS}

It is important to emphasize that the preservation of the third eyelid lacrimal gland in dogs with cherry eye condition is essential during the surgery for its treatment. The reason for this is due to the induction of ophthalmic disturbances associated with keratoconjunctivitis sicca in response to the removal of this gland.

\section{SOURCE AND MANUFACTURES}

1 Ciclosporina 1\%, Ophthalmos Ind. e Com. de Prod. Farmacêuticos Ltda, São Paulo, Brazil.

${ }^{2}$ Viscotears ${ }^{\circledR}$, Ciba Vision AG, Novartis Company, Basileia, Swiss.

\section{REFERENCES}

BROOKS D.E. Canine conjunctiva and nictitanting membrane. In: GELLAT, K.N. Veterinary ophthalmology. Philadelphia : Lea \& Febiger, 1991. Cap.8, p.290-306.

DUGAN, S.J. et al. Clinical and histologic evaluation of the prolapsed third eyelid gland in dogs. Journal of American Veterinary Medical Association, v.201, n.12, p.1861-1867, 1992.

GELLAT, K.N. Canine lacrimal and nasolacrimal diseases. In: GELLAT, K.N. Veterinary ophthalmology. Philadelphia : Lea \& Febiger, 1991. Cap.7, p.276-289.

GELLAT, K.N. et al. Evaluation of tear formation in the dog, using a modification of the schirmer tear test. Journal of American Veterinary Medical Association, v.166, n.4, p.365$370,1975$.

Ciência Rural, v.34, n.3, mai-jun, 2004. 
HELPER, L.C. et al. Surgical induction of keratoconjunctivitis sicca in the dog. Journal of American Veterinary Medical Association, v.165, n.2, p.172-174, 1974.

KASWAN, R.L.; MARTIN, C.L. Surgical correction of third eyelid prolapse in dogs. Journal of American Veterinary Medical Association, v.186, n.1, p.83, 1985.

McLAUGHLIN, S.A. et al. Effect of removal of lacrimal and third eyelid glands on schirmer tear test results in cats. Journal of American Veterinary Medical Association, v.193, n.7, p.820822, 1988.

MOORE, C.P. Diseases and surgery of the lacrimal secretory system. In: GELLAT, K.N. Veterinary ophthalmology. Baltimore: Williams \& Wilkins, 1998. Cap.16. p.586-599.

MORGAN, R.V.; ABRAMS, K.L. Topical administration of cyclosporine for treatment of keratoconjunctivitis sicca in dogs. Journal of American Veterinary Medical Association, v.199, n.8, p.1043-1046, 1991.
MORGAN, R.V.; DUDDY, J.M.; McCLURG, K. Prolapse of the gland of the third eyelid in dogs: a retorspective study of 89 cases (1980 to 1990). Journal of the American Animal Hospital Association, v.29, n.1, p.56-60, 1993.

SAITO, A. et al. The effect of third eyelid gland removal on the ocular surface of dogs. Veterinary Ophthalmology, v.4, n.1, p.13-18, 2001.

SANSOM, J. et al. Treatment of keratoconjunctivitis sicca in dogs with cyclosporine ophthalmic ointment: a European clinical field trial. Veterinary Record, v.137, n.11, p.504-507, 1995.

STANLEY, R.G.; KASWAN, R.L. Modification of the orbital rim anchorage method for surgical replacement of the gland of the third eyelid in dogs. Journal of American Veterinary Medical Association, v.205, n.10, p.1412-1414, 1994.

WILKIE, D.A. Management of keratoconjunctivitis sicca in dogs. Continuing Education for the Practicing Veterinary, p.58- 63, 1993. 